\title{
PEMANFAATAN LAHAN PERTANIAN DENGAN MENGGUNAKAN SISTEM HIDROPONIK GUNA MENINGKATKAN PEREKONOMIAN WARGA RT.05 / RW.14 DESA CEMANI
}

\author{
Muhammad Sabandi ${ }^{1}$, dan Anggota ${ }^{2}$ \\ ${ }^{1}$ Universitas Sebelas Maret \\ Coresponding author: muhsabandi@staff.uns.ac.id
}

\begin{abstract}
ABSTRAK
Perkembangan teknologi dalam sektor pertanian seiring berjalannya tahun semakin pesat. Namun, dalam hal semacam ini tentu tidak selalu menghasilkan dampak yang baik. Bisa dilihat dari para penduduk yang khususnya berprofesi sebagai petani, mereka tertinggal dalam memanfaatkan kemajuanknologi sehingga tidak bisa memperoleh keuntungan yang maksimal dari kegiatan usaha yang dilakukannya. Hal ini dikarenakan semakin sempitnya lahan pertanian akibat dari banyaknya sektor industri dan jasa, sehingga kegiatan usaha pertanian konvensial semakin tidak kompetitif karena tingginya harga lahan. Desas-desus seperti ini berkaitan dengan alih fungsi lahan pertanian menjadi lahan pemukiman ataupun lahan industri untuk membangun pabrik-pabrik besar. Pelaksanaan KKN UNS 223 di Desa Cemani ini bertujuan untuk memberikan pengetahuan kepada para penduduk mengenai budidaya tanaman hidroponik, serta mendorong mereka supaya kembali bergerak untuk berproduksi secara maksimal di masa pandemi ini. Dengan sistem hidroponik ini diharapkan menjadi salah satu alternatif bagi penduduk yang memiliki lahan terbatas sehingga dapat dijadikan sebagai sumber penghasilan yang memadai. Hidroponik sendiri merupakan metode bercocok tanam dengan menggunakan media tanam berupa air. Hal tersebut dilakukan karena fungsi tanah sebagai pendukung akar tanaman dan perantara larutan nutrisi dapat digantikan dengan mengalirkan atau menambahkan nutrisi, dan oksigen melalui media tersebut. Metode pelaksanaan program ini dilaksanakan dalam bentuk pendidikan, pelatihan, dan pelayanan masyarakat dengan memanfaatkan limbah plastik. Pelatihan dilakukan selama satu hari yang diikuti oleh penduduk sekitar dalam lingkup RT.05 / RW.14. Hasil dari pelatihan ini yakni antusiasme peserta dengan kegiatan pelatihan budidaya tanaman hidroponik dan pengetahuan serta pemahaman yang baru untuk dapat mengoptimalkan halaman rumah mereka sehingga dapat bermanfaat dengan baik dalam segi estetika bahkan dalam segi perekonomian.
\end{abstract}

Kata kunci: Desa Cemani, Hidroponik, KKN ,Lahan Sempit

\section{PENDAHULUAN}

Pertanian merupakan salah satu dari sekian banyak sektor yang dapat digunakan untuk memajukan perekonomian daerah, atau bahkan negara sekalipun. Peran penting dari sektor pertanian yaitu kurang lebihnya dapat dijadikan sebagai tumpuan sumber penghasilan bagi masyarakat. Hal ini tentu menguntungkan jika mengingat Indonesia disebut sebagai negara agraris atau negara yang sebagian wilayahnya merupakan lahan pertanian. Kebanyakan para petani biasanya menggunakan tanah sebagai media dalam mengembangkan sektor pertanian. Selain itu, hal yang paling penting selain media tanah adalah lahan yang lapang atau luas.

Saat ini, kebutuhan bahan pangan seperti buah-buahan atau sayur-sayuran telah 
meningkat. Hal ini sejalan dengan bertambahnya populasi jumlah penduduk yang juga meningkat. Namun, di sisi lain dengan pertambahan jumlah penduduk yang mulai "melek" akan IPTEK, kemajuan pada sektor perindustrian juga berkembang pesat. Banyak penduduk yang mulai melebarkan sayap pada bidang ini, dengan membangun pabrik-pabrik industri di wilayah perkotaan. Bahkan terkadang sudah merambah ke pedesaan karena lahan di perkotaan sudah mulai penuh. Akhirnya, keadaan yang seperti ini lambat laun telah menggeser banyak lahan pertanian baik di perkotaan maupun di pedesaan. Kondisi tersebut membuat akses penduduk untuk dapat menghasilkan hasil pertanian menjadi terhambat. Sedangkan, permintaan pada petani nyaris sudah melampaui batas. Di beberapa wilayah, sebagian penduduk bahkan tidak mendapatkan kebutuhan pangan yang layak.

Berdasarkan survey yang telah kami lakukan di Desa Cemani, desa ini merupakan salah satu contoh yang banyak menerapkan alih fungsi lahan pertanian menjadi lahan industri. Tentu menjadi sasaran yang tepat bagi kami para mahasiswa KKN UNS 223 untuk membantu permasalahan penduduk yang kekurangan lahan untuk pertanian. Di sini kami memiliki ide atau cara lain untuk memanfaatkan lahan sempit sebagai usaha untuk mengembangkan hasil pertanian, yaitu dengan cara bercocok tanam secara hidroponik.

Hidroponik merupakan lahan dari budidaya pertanian tanpa menggunakan tanah sebagai media. Sehingga, hidroponik ini hanya berupa aktivitas pertanian yang dilakukan dengan menggunakan air sebagai media untuk menggantikan tanah, dan dengan tambahan nutrisi untuk mendukung pertumbuhan. Sistem bercocok tanam secara hidroponik ini dapat diterapkan pada lahan yang sempit. Baik di luar ataupun di dalam rumah, seperti di pekarangan rumah, dapur dan garasi. Keuntungan dari bercocok tanam dengan sistem hidroponik adalah kurang lebih kebersihan tanaman lebih terjaga, tidak diperlukannya pengolahan lahan dan pengendalian gulma, media tanam steril, penggunaan air dan pupuk sangat efisien, tanaman dapat dibudidayakan terus tanpa mengandalkan musim, dapat diterapkan pada lahan yang sempit, serta terlindung dari hujan dan matahari secara langsung.

Media tanam yang digunakan dalam hidroponik tidak mengandung nutrisi yang dibutuhkan oleh tanaman. Penambahan nutrisi mutlak dibutuhkan untuk budidaya tanaman dengan sistem hidroponik, baik unsur hara esensial makro maupun mikro. Penyerapan nutrisi tanaman dipengaruhi oleh 
media tanam. Media tanam merupakan tempat akar tanaman menyerap unsur-unsur hara yang dibutuhkan oleh tanaman. Media tanam yang baik merupakan media yang dapat mendukung pertumbuhan dan kehidupan tanaman.

Adapun tujuan kegiatan ini adalah untuk memberikan pemahaman mengenai metode hidroponik, dan memberikan keterampilan warga untuk mengaplikasikan sendiri budidaya tanaman. Sedangkan manfaat kegiatan ini adalah untuk meningkatkan pengetahuan dan keterampilan untuk mengolah lahan yang terbatas menjadi lahan pertanian yang bernilai jual serta meningkatkan kemampuan ekonomi masyarakat.

\section{METODE}

Dalam upaya memberikan pemahaman dan pengetahuan, serta keterampilan kepada penduduk Desa Cemani mengenai metode hidroponik dilakukan melalui penyuluhan dan pelatihan, yaitu dengan sosialisasi materi dan melaksanakan praktik secara langsung tentang budidaya tanaman hidroponik. Saat dilaksanakan praktik, kami juga membuka sesi tanya jawab mengenai budidaya tanaman hidroponik itu sendiri. Hal ini dilakukan sebagai upaya meningkatkan keterampilan warga dalam budidaya tanaman hidroponik dengan memanfaatkan lahan garasi atau teras rumah dan mengaplikasikannya.

Penyuluhan dan pelatihan budidaya tanaman hidroponik di Desa Cemani, Kecamatan Grogol, Kabupaten Sukoharjo ini dilaksanakan di kediaman salah satu warga RT.05 / RW.14 sekaligus seorang mahasiswa KKN UNS 223 dengan memanfaatkan limbah plastik yang mudah didapatkan. Hal ini juga berkaitan dengan pemanfaatan limbah plastik yang sukar terurai. Pelatihan ini dilakukan selama satu hari yang dikuti oleh warga sekitar. Materi pelatihan dilakukan dengan metode pemaparan secara singkat, kemudian dilanjutkan praktik budidaya tanaman hidroponik. Mitra yang diajak bekerja sama oleh anggota KKN UNS 223 ini merupakan warga sekitar lingkup RT 05 / RW 14. Mekanisme pemilihan mitra warga RT.05 / RW.14 yaitu didasarkan alasan karena mereka tinggal di salah satu lingkungan yang merupakan hasil dari alih fungsi lahan pertanian menjadi lahan pemukiman. Selain itu, rumah mereka memiliki banyak lahan atau tempat yang longgar sehingga bisa dilakukan penanaman hidroponik walaupun syarat penanaman hidroponik ini tidak harus dilakakukan di lahan yang luas.

Adapun proses penyuluhan dan budidaya tanaman bayam merah, pakcoy, dan 
selada keriting dengan metode hidroponik adalah sebagai berikut:

1. Melakukan sosialisasi mengenai program pengabdian kepada masyarakat atau program kerja $\mathrm{KKN}$ UNS 223 yang dilaksanakan di Desa Cemani RT.05 / RW.14

2. Berkoordinasi dengan Ketua RT.05 untuk teknik, waktu, dan tempat pelaksanaan

3. Melakukan penyuluhan dan pelatihan budidaya tanaman hidroponik secara singkat (berupa pemaparan materi)

4. Melakukan praktik atau pelatihan cara budidaya tanaman hidroponik dengan langkah-langkah sebagai berikut.

a. Menyiapkan alat dan bahan untuk membuat instalasi hidroponik berupa pipa paralon, bor listrik, pipa L, mesin pompa, netpot, rockwool, pisau /cutter, benih, nampan, plastik hitam, dan lidi.

b. Membuat instalasi hidroponik dengan memotong pipa dan membuat lubang tanam pada pipa paralon tersebut dengan jarak antar lubang 10-15 cm.

c. Merangkai pipa yang sudah dilubangi menjadi rangkaian instalasi hidroponik secara vertikal. d. Menyambungkan instalasi dengan mesin pompa dan tandon air.

e. Memasang netpot pada lubang tanam.

f. Melakukan penyemaian benih bayam merah, pakcoy, dan selada keriting. Penyemaian benih dilakukan dengan cara: (i) memotong rockwool dengan ukuran $2,5 \times 2,5 \mathrm{~cm}$ tetapi tidak sampai putus dan meletakkannya di nampan semai. (ii) membasahi rockwool dengan air. (iii) rockwool lalu dilubangi dengan menggunakan lidi dan meletakkan benih dalam lubang tersebut. (iv) rockwool yang telah diisi dengan benih disiram sedikit dengan air lalu ditutup dengan plastik hitam dan didiamkan semalam. (v) setelah semalam, plastik dibuka dan nampah semai diletakka pada tempat yang terkena sinar matahari langsung. (vi) benih yang telah tumbuh dapat dipindah ke instalasi hidroponik setelah berumur 5 hari setelah semai.

5. Melakukan evaluasi kegiatan.

Evaluasi dilakukan setelah penyuluhan dan praktik atau pelatihan budidaya tanaman hidroponik selesai dilaksanakan, sebagai 
bahan evaluasi di kemudian hari.

\section{HASIL, PEMBAHASAN DAN DAMPAK}

Penyuluhan mengenai metode tanam hidroponik terlaksana dengan baik dan mendapat apresiasi tinggi dari masyarakat Desa Cemani. Masyarakat mendapat gambaran tentang proses pembuatan Hidroponik serta alat dan bahan-bahan yang digunakan. Masyarakat juga merasa memiliki kegiatan di masa pandemi dirumah untuk mengembangkan dan mengisi waktu luang dengan bermanfaat atas kegiatan ini.

Pembuatan hidroponik kami contohkan terlebih dulu agar menjadi bahan gambaran masyarakat melakukannya dirumah secara mandiri. Hasilnya bisa dilihat secara bertahap dan kembali kepada individu masing-masing masyarakat terutama bibit apa saja yang akan ditanam. Inisiatif besar ditujukan masyarakat Desa Cemani dalam penggunaan lahan yang kita gunakan untuk menempatkan hidroponik contoh agar ketika tumbuh bisa dirawat dan diambil sebagai kebutuhan yang bermanfaat. Adanya penyuluhan, dan pelatihan mengenai budidaya bayam merah, pakcoy, dan selada keriting dengan metode hidroponik yaitu peserta penyuluhan merasa antusias dengan kegiatan pelatihan budidaya tanaman hidroponik yang telah dilaksanakan. Pelatihan memberikan pengetahuan dan pemahaman baru bagi warga untuk dapat mengoptimalkan halaman rumah mereka sehingga dapat bermanfaat dengan baik dalam segi estetika bahkan kedepannya dalam segi perekonomian.

Tabel 1. Tingkat Pengetahuan Kelompok Mitra

\begin{tabular}{llll}
\hline \hline No & \multicolumn{3}{c}{ Uraian } \\
\hline 1 & $\begin{array}{l}\text { Mengetahui } \\
\text { Hidroponik }\end{array}$ & cara membuat & rangkaian \\
\hline
\end{tabular}

Sumber: Analisis Kuisioner, 2021

\section{Penulisan Gambar}
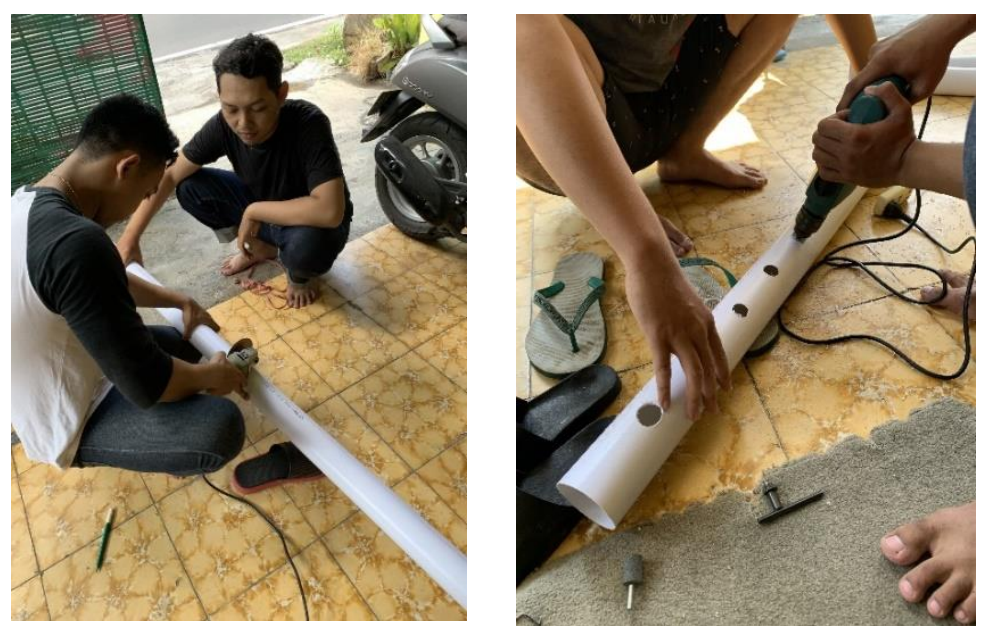

Gambar 1. (a) Pemotongan Pipa Paralon untuk Instalasi Hidroponik (b) Pembuatan

Lubang Tanam Instalasi Hidroponik Sumber: Dokumentasi Kegiatan, 2021 


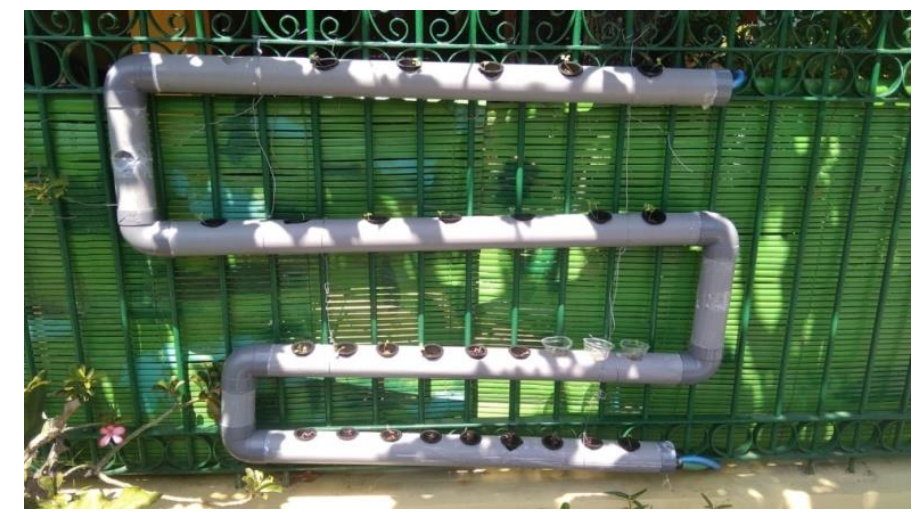

Gambar 2. Hasil Akhir Instalasi Hidroponik Sumber: Dokumentasi Kegiatan, 2021

\section{PENUTUP}

\section{SIMPULAN}

Kesimpulan dari kegiatan pembuatan rangkaian Hidroponik di masyarakat Desa Cemani yang telah dilaksanakan yaitu:

1. Masyarakat Desa Cemani mampu memperluas minat dan bakat penanaman tanaman hidroponik.

2. Masyarakat Desa Cemani menambah pengetahuan tentang cara merawat tanaman hidroponik dengan baik dan benar.

3. Masyarakat Desa Cemani memiliki kegiatan yang bermanfaat di era pandemi.

\section{UCAPAN TERIMA KASIH}

1. Allah SWT yang telah menghendaaki kegiatan berjalan lancar.

2. UPKKN LPPM Universitas Sebelas Maret (UNS) yang telah memfasilitasi pelaksanaan kegiatan $\mathrm{KKN}$ periode Juli - Agustus 2021.

3. Bapak Hadi Indrianto S.T., selaku Kepala Desa dan semua perangkat Desa Cemani yang menerima mahasiswa untuk KKN di Desa Cemani.

4. Bapak Sugiyono selaku Ketua RW 14 Desa Cemani yang memperbolehkan kita membantu Posyandu dan Program Instalasi Hidroponik.

5. Dzakwan dan keluarga yang memfasilitasi rumahnya sebagai pos KKN UNS 223 Desa Cemani.

\section{DAFTAR PUSTAKA}

Roidah IS. 2014. Pemanfaatan Lahan Dengan Menggunakan Sistem Hidroponik. Jurnal Bonorowo 1(2): 43-49.

Bayu WN. 2016. Cara Menanam Bayam Merah Hidroponik. http://hidroponikpedia.com/step-bystep-cara-menanam-bayam-merahhidroponik/, diakses pada Kamis, 2 September pkl 18.14 WIB.

Tashandra, Nabilla. 2021. 5 Sayur Hidroponik 
yang Mudah Ditanam, Cocok untuk Pemula.

https://lifestyle.kompas.com/read/2021/

$\underline{\text { 01/06/153000920/5-sayur-hidroponik- }}$

yang-mudah-ditanam-cocok-untuk-

pemula?page $=$ all , diakses pada Kamis,

2 September pkl 18.18 WIB. 